\title{
Relationships between agronomic characters and ecogeographical factors in a collection of French perennial ryegrass populations
}

\author{
F Balfourier *, G Charmet \\ Station d'Amélioration des Plantes, INRA, 63039 Clermont-Ferrand, France
}

(Received 8 April 1991; accepted 30 June 1991)

\begin{abstract}
Summary - Relationships between agronomic traits of natural populations of perennial ryegrass and ecogeographical (ie climatic, ecological and geographical) factors of their original sites were studied using multivariate correspondence analysis. Initially, only agronomic variables were used to describe relationships within agronomic traits. These different variables were projected on the same 1-2 factorial plan. The similarity of the different curves which joined the successive classes of the same variable has been discussed: some obvious relationships appear between traits such as rust susceptibility, growth habit, heading date and frost susceptibility; on the other hand, all vigour traits seem to be highly correlated to each other. In order to study relationships between agronomic and ecogeographical traits, different ecogeographical factors (considered as additional variables) were independently projected on the same 1-2 plan. Relationships were established from the respective position of these 2 types of variable. Climatic data seem to be more important than ecological factors in explaining genetic variability. However, some ecological features, eg habitat and farming management, also influenced some agronomic traits such as spring growth or persistency. The interest of using such ecogeographical data to manage genetic resources and study evolutive strategies is discussed.
\end{abstract}

Lolium perenne L = ryegrass / genetic resource / multivariate analysis / natural population / ecogeographical data

Résumé - Relations entre caractères agronomiques et facteurs écogéographiques pour un échantillon ensemble de populations françaises de ray-grass anglais. $\dot{A}$ partir d'un échantillon de 547 populations naturelles de ray-grass anglais, (dont une dizaine de caractéristiques agronomiques ont été décrites dans un article précédent, à la suite d'une évaluation en 4 lieux), les relations entre les caractéristiques agronomiques et les facteurs écogéographiques de leur site d'origine sont étudiées.

Lors des prospections, une fiche de site a permis d'enregistrer les caractéristiques écologiques de chaque site collecté : habitat, mode d'exploitation, présence de fumure organique, importance du piétinement, degré d'humidité du site, abondance de l'espèce et maturité. De plus, à l'aide de cartes de l'Institut géographique national, la localisation exacte de chaque site de collecte a été relevée, notamment par sa latitude et son altitude.

En partant des données climatiques enregistrées par les stations de la Météorologie nationale situées à proximité de chaque site de collecte, une base de données météorologiques a été réalisée. Chaque site est ainsi caractérisé par 11 variables climatiques quantitatives (températures, précipitations, etc) ou qualitatives (ex : nombre de mois d'aridité, etc).

Dans un premier temps, les relations entre les différentes variables agronomiques, mesurées dans chacun des lieux, sont étudiées à l'aide d'une analyse factorielle des correspondances. La projection de ces variables, découpées en classes, sur le plan principal 1-2 nous permet d'observer, par une série de graphiques (figs 1-7), les liaisons entre chacune des variables : sur le premier axe, on retrouve en général une liaison entre les différentes variables liées à la vigueur (vigueur de printemps, été, automne et persistence), tandis que le second axe est lié à la physiologie de la plante, et des caractéristiques comme le port, la sensibilité aux rouilles ou encore la sensibilité au froid semblent être en correspondance.

Dans un deuxième temps, les variables écogéographiques (ie climatiques, écologiques et topographiques), après avoir été, si nécessaire, transformées en variables qualitatives, sont utilisées comme variables illustratives dans la précédente analyse factorielle des correspondances. La projection de ces variables écogéographiques, sur le même plan factoriel 1-2, permet d'illustrer, en fonction de leur proximité avec les variables liées à la température sont négativement corrélées aux variables agronomiques, les relations existant entre ces 2 types de variables. La même série de graphiques (figs 1-7) permet ainsi d'apprécier, pour chaque variable agronomique, les variables écogéographiques les plus en correspondance : les variables liées à la température sont négativement corrélées aux variables de vigueur et positivement à la sensibilité au froid à l'alternativité et à la remontaison. Par contre les variables liées aux précipitations et à l'humidité sont positivement corrélées à la sensibilité aux rouilles, à l'aspect estival et à la persistance. Enfin, altitude et latitude sont également très liées aux caractéristiques agronomiques.

\footnotetext{
* Correspondence and reprints
} 
Une série de tableaux présente, pour les variables écogéographiques les plus représentatives, les moyennes de chaque variable agronomique comparées à la moyenne générale. Parmi les variables écologiques, habitat et mode d'exploitation sont les variables influençant le plus les caractéristiques agronomiques.

L'intérêt de l'utilisation des variables écogéographiques, pour la gestion des ressources génétiques et létude des stratégies évolutives, est discuté.

Lolium perenne $L$ = ray-grass anglais / ressource génétique / analyse des données / population naturelle / donnée écogéographique

\section{INTRODUCTION}

An understanding of the kinds of adaptation which result from the selection pressure of complex environmental factors is fundamental to the work of a plant breeder. It can allow him to develop the most interesting sampling strategies of genetic resources, and to increase the efficiency of plant breeding programs by the introduction of new sources of genetic variation.

For different species, many authors have studied the relationships between agronomic or physiological plant data and the ecological characteristics of their original site. They have shown that macroclimate could have a major effect. Investigations have recently been made eg in barley (Weltzien, 1989) and lentil (Erskine et al, 1989 ) in wild populations of diverse geographical origins.

Concerning herbage legumes, many studies have been undertaken both at the interspecific level (Prosperi et al, 1989) on annual medics and at the intraspecific level (Caradus et al, 1989) on white clover.

Finally, in herbage grasses, most work relating to the relationships between ecological and agronomic traits has been aimed at perennial ryegrass in Europe (studies undertaken by the Welsh Plant Breeding Station: Hayward and Breese, 1966, 1968; Lorenzetti et al, 1971; Tyler and Chorlton, 1976, 1978; Tyler et al, 1984; Humphreys and Eagles, 1988) and also in New Zealand (Forde and Suckling, 1980). But some studies have also been performed on cocksfoot (Tyler, 1979; Lumaret, 1984) and tall fescue (Veronesi and Falcinelli, 1988). All these authors have shown that a combination of climatic, ecological and geographical factors (ie "ecogeographical" factors) contribute more or less to the genetic differentiation of indigenous populations on their original site.

In this paper, from the study of a wide sample of 547 wild French populations of perennial ryegrass, we first present the relationships within some agronomic traits of these populations, and secondly the correlations between agronomic traits and ecogeographical factors from their site of origin.

\section{MATERIALS AND METHODS}

\section{Presentation of the different variables}

Details concerning the origin of the 547 perennial ryegrass accessions studied are given in Charmet et al (1990): 547 natural populations of perennial ryegrass were collected as seed from all over France in 1983 and 1984, then evaluated at 9 sites in spaced plant nurseries. Ten agronomic traits were observed over a 3-year life cycle: alternativity, growth habit, rust susceptibility, frost susceptibility, spring, summer and autumn growth, persistence, aftermath heading and heading date.

An analysis of variance of these traits for 3 sites with a complete data set revealed the considerable importance of population $x$ location interactions in the total variation for 6 out of the 10 traits: susceptibilities and vigour traits. Principal component analyses, carried out on the interaction terms in 8 locations for each trait, allowed a reduction to 4 as the minimum number of locations required to describe the most important part of the interaction (cf Charmet et al, 1990).

Consequently, we will consider in this paper only these 4 locations: Rodez (01), Mont de Marsan (02), Bourg Lastic (10) and Le Pin au Haras (11). Each population is characterized by 28 agronomic values: phenotypic means of 6 traits (rust susceptibility, frost susceptibility, spring, summer and autumn growth, and persistence) in each of the 4 locations retained, plus 4 adjusted means of the 4 stable traits (alternativity-ie, ability to flower in the sowing year-growth habit, aftermath heading and heading date). Abbreviations used for the 28 agronomic variables are given in table $\mathrm{I}$.

Furthermore, 7 ecological variables were estimated by collectors on each site of collection: general habitat (roadside, path, fallow, meadow or various), farming management (mowed, grazed, or mowed/grazed - ie, hay plus aftermath grazing), presence of organic manure ( 2 classes), humidity ( 3 classes), specific abundance ( 3 classes), level of maturity ( 3 classes) and trampling intensity ( 3 classes). Unfortunately, at some 
Table I. Name, scale and abbreviation of the 28 agronomic traits.

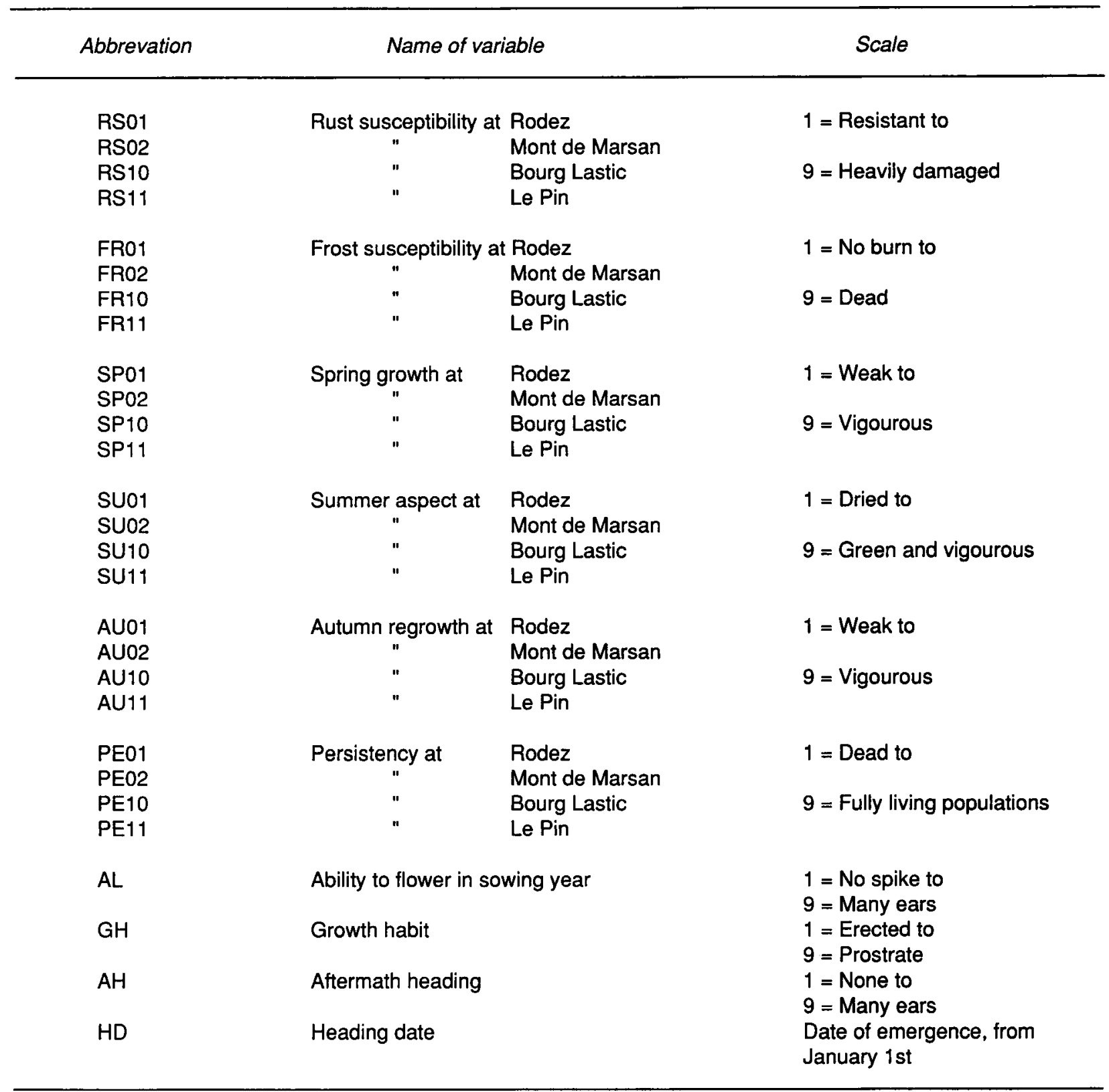

collection sites, habitat and farming management were not well known.

A climatic data base was built using adjacent weather station data from The National Meteorological Office (Garnier, 1966; Kessler and Chambraud, 1986). Generally, 30 year averages were considered for each of the variables and classes were determined and coded from the lowest to the highest values; 11 climatic variables were used: accumulated rainfall from March to October ( $p m o$ ), potential evapotranspiration and hydric balance for the same period (etp, $h b$ ), mean annual temperature in ${ }^{\circ} \mathrm{C}(t)$, mean daily minimum temperature for the coldest month $(m)$, mean daily maximum temperature for the warmest month $(M)$, number of months with mean minimum temperature below $0{ }^{\circ} \mathrm{C}$ $(n m 0)$, with mean monthly temperature $>10^{\circ} \mathrm{C}(n 10)$, with mean maximum temperature $>25^{\circ} \mathrm{C}(n 25)$, with aridity (nar) (ie number of months with $P<=2 t$, where $P=$ monthly rainfall and $t=$ monthly temperature), and the humidity index of Emberger $Q$

$$
\left(Q=\frac{P}{((M+m) / 2)(M-m)}\right) .
$$

Four classes of equal size were determined for each variable, except for $n m 0$ and nar (3 classes).

Finally, the geographical co-ordinates of collection sites were obtained from The National Geographic Institute maps: altitude (alt-4 classes), latitude (lat-4 
classes) and localisation (name of 15 large administrative regions in France).

Table II gives the range variation for each climatic and geographical trait at the collection site, and table III gives the limits of each class for the same variables.

\section{Statistical development}

Simple linear correlations between the 28 agronomic and 9 ecogeographical traits were calculated.

The 28 agronomic variables were then transformed to qualitative variables by creating 3 classes of equal

Table II. Mean and range of variation of each climatic and geographical trait of collection sites.

\begin{tabular}{|c|c|c|c|}
\hline Variables & Mean & Range & Standard deviation \\
\hline $\begin{array}{l}\text { pmo (Accumulated rainfall from } \\
\text { march to october) }\end{array}$ & 561 & $328-1090$ & 141 \\
\hline etp (Potential evapotranspiration) & 709 & $575-1075$ & 111 \\
\hline hb (Hydric balance) & -148 & $-687-+515$ & 188 \\
\hline$t \quad$ (Mean annual temperature) & 10.65 & $4.70-15.60$ & 1.62 \\
\hline $\begin{array}{l}\text { (Mean daily min temp } \\
\text { of the coldest month) }\end{array}$ & -0.06 & $-8.00+6.00$ & 2.00 \\
\hline $\begin{array}{l}M \quad \text { (Mean daily min temp of the } \\
\text { warmest month) }\end{array}$ & 24.60 & $+18.00-+33.00$ & 2.43 \\
\hline $\begin{array}{l}n m 0 \text { (No of months with mean } \\
\quad \min \text { temp }<0^{\circ} \mathrm{C} \text { ) }\end{array}$ & 1.72 & $0-6$ & 1.74 \\
\hline $\begin{array}{l}n 10 \text { (No of months with mean } \\
\text { monthly temp }>10^{\circ} \mathrm{C} \text { ) }\end{array}$ & 6.31 & $0-10$ & 0.97 \\
\hline $\begin{array}{l}\text { n25 (No of months with mean } \\
\max \text { temp }>25^{\circ} \mathrm{C} \text { ) }\end{array}$ & 1.08 & $0-4$ & 1.20 \\
\hline $\begin{array}{l}\text { nar (No of months with aridity } \\
\quad P<2 t)\end{array}$ & 0.25 & $0-4$ & 0.65 \\
\hline$Q \quad$ (Humidity index of Emberger) & 3.06 & $1.36-9.89$ & 1.22 \\
\hline alt (Altitude) & 297 & $0-1800$ & 269 \\
\hline lat (Latitude) & 51.53 & $47.18-56.52$ & 2.35 \\
\hline
\end{tabular}

Table III. Limits of classes for each illustrative trait used in the multivariate correspondence analysis.

\begin{tabular}{lcccc}
\hline & \multicolumn{4}{c}{ Limits of classes } \\
\cline { 2 - 5 } Variables & Class 1 & Class 2 & Class 3 & Class 4 \\
\cline { 2 - 5 } pmo $(\mathrm{mm})$ & $328-454$ & $454-529$ & $529-625$ & $625-1090$ \\
etp $(\mathrm{mm})$ & $575-625$ & $625-675$ & $675-725$ & $725-1075$ \\
$h b \quad(\mathrm{~mm})$ & $-687--254$ & $-254--166$ & $-166--40$ & $-40-515$ \\
$t$ & $\left({ }^{\circ} \mathrm{C}\right)$ & $9.8-10.5$ & $10.5-11.5$ & $11.5-15.6$ \\
$m\left({ }^{\circ} \mathrm{C}\right)$ & $-8-9.8$ & $-2-0$ & $0-1$ & $1-6$ \\
$M \quad\left({ }^{\circ} \mathrm{C}\right)$ & $18-22$ & $22-24$ & $24-26$ & $26-33$ \\
$n m 0$ & 0 & $1,2,3$ & $4,5,6$ & $/$ \\
$n 10$ & 4,5 & 6 & 7 & 8,910 \\
$n 25$ & 0 & 1 & 2 & 3,4 \\
$n a r$ & 0 & 1 & $>1$ & $3.48-9.89$ \\
$Q$ & $1.36-2.25$ & $2.25-2.69$ & $2.69-3.48$ & $3.48-1800$ \\
alt $(\mathrm{m})$ & $0-110$ & $110-208$ & $208-398$ & $398-50.52$ \\
lat $(\mathrm{gr})$ & $47.18-49.43$ & $49.43-51.54$ & $51.54-53.40$ & $53.40-56.52$ \\
\hline
\end{tabular}


size for each. A multivariate correspondence analysis (Benzecri, 1973) was thus carried out using these 28 transformed agronomic variables. Respective positions of each agronomic class were projected on a plan defined by the factors 1 and 2 as axes. Relationships within agronomic traits were observed by studying the similarity of the different curves which joined together the successive classes of the same variable (Volle, 1985).

A second matrix containing classes of the different ecogeographical factors, which were considered as additional variables, was independently projected on the same plane. Relationships between agronomic traits and classes of the different ecogeographical factors were established from the respective positions of these 2 types of variable.

Finally, for each of the 28 agronomic variables, means by classes of some ecogeographical variables were calculated and compared to the overall mean of the 547 populations.

\section{RESULTS}

\section{Distribution of collected populations}

As reported previously (Charmet et al, 1990), perennial ryegrass populations were collected all over France, under all the different geographical and microclimate environmental conditions found in France ( $c f$ table II).

Unfortunately, since collection was made by different research teams, the distribution of ecological variables, such as habitat and in particular farming management, are not random throughout the collection area; for instance, only 33 sites were registered as having a high level of organic manure. Regarding general habitat, fallow sites are underevaluated (only 30 sites), while meadows are not well represented in south-east and central France. This can be explained by the fact that, according to the sampling strategies, collectors chose to collect seeds; consequently, some areas are obviously underevaluated.

\section{Correlations between agronomic and ecogeographical quantitative traits}

Table IV gives the correlation between the 28 agronomic and 9 ecogeographical traits, and the correlation matrix within these 9 ecogeographical variables. Although the correlation coefficients are often statistically significant because of the high number of degrees of freedom (545; at 0.05 , the threshold is 0.086), they are generally low. Therefore, we have only presented the correlation coefficients $>0.20$, which are the most interesting ones.

Climatic traits of temperature $(m, M, t)$ are negatively correlated with rust susceptibility and agronomic vigour traits (spring growth, summer aspect, autumn regrowth and persistence), and positively with frost susceptibility, alternativity and aftermath heading.

Variables concerning rainfall and humidity (pmo, $Q, h b$ ) are positively correlated with rust susceptibility, summer aspect and persistence, and negatively with frost susceptibility and alternativity. etp is mainly correlated with persistence (negatively) and alternativity (positively).

Altitude is positively correlated with rust susceptibility and growth habit; but it has no influence on spring growth. Finally, latitude is positively correlated with vigour traits and heading date, and negatively with frost susceptibility and alternativity.

Finally, the correlation matrix within the 9 ecogeographical traits indicates the opposition between "temperature variables" $(m, M, t)$ and "water variables" (pmo, $Q, h b)$.

\section{Multivariate correspondence analysis}

The relative contribution of each active variable (agronomic variables) to the inertia explained by the first axis is given in table $\mathrm{V}$. The first 2 principal factors account for only 7 and $5 \%$ respectively of total inertia. However, according to Benzecri (1979) and Volle (1985), for a multivariate correspondence analysis with a large number of variables, these proportions give a very pessimistic view of the information actually contributed by axes, which does not concern us unduly.

The first axis 1 can be interpreted as an axis of "general vigour" since principal accumulated contributions are those of autumn regrowth $(17.9 \%)$, summer aspect $(16.9 \%)$, persistence $(16.7 \%)$ and spring growth (12.7\%). Axis 2 is explained by frost and rust susceptibility (respectively $22.3 \%$ and $18.6 \%$ ). It can be called a "physiological axis".

Results are presented on the plan defined by axes 1 and 2. Abbreviations used for the traits are described in Materials and Methods, and have been printed in capitals for active variables (ie agronomic traits) and in lower case for additional variables (ie ecogeographical traits), ex- 
Table IV. Correlation between the 28 agronomic and 9 ecogeographical traits, and matrix of correlation within 9 ecogeographical factors.

\begin{tabular}{|c|c|c|c|c|c|c|c|c|c|}
\hline & $m$ & $M$ & $t$ & etp & $Q$ & $h b$ & pmo & alt & lat \\
\hline $\begin{array}{l}\text { RSO1 } \\
\text { RSO2 }\end{array}$ & -0.39 & -0.28 & -0.45 & -0.20 & 0.20 & 0.22 & & 0.46 & \\
\hline RS 10 & -0.20 & & -0.23 & & & & & & \\
\hline RS11 & & & & 0.26 & & & 0.22 & 0.38 & -0.37 \\
\hline $\begin{array}{l}\text { FR01 } \\
\text { FR02 }\end{array}$ & 0.32 & 0.29 & 0.45 & 0.27 & & -0.24 & & & -0.37 \\
\hline $\begin{array}{l}\text { FR10 } \\
\text { FR11 }\end{array}$ & & & 0.27 & & & & & & -0.31 \\
\hline $\begin{array}{l}\text { SP01 } \\
\text { SP02 }\end{array}$ & & & -0.26 & & & & & & 0.25 \\
\hline SP10 & & & -0.24 & & & & & & 0.31 \\
\hline SP11 & & & -0.21 & -0.25 & & 0.20 & & & 0.26 \\
\hline $\begin{array}{l}\text { SU01 } \\
\text { SU02 }\end{array}$ & -0.21 & & -0.23 & & & & & & \\
\hline $\begin{array}{l}\text { SU10 } \\
\text { SU11 }\end{array}$ & -0.33 & -0.36 & -0.46 & -0.34 & $\begin{array}{l}0.29 \\
0.21\end{array}$ & 0.35 & 0.20 & 0.22 & 0.34 \\
\hline AU01 & & 0.22 & & 0.30 & & -0.26 & & & \\
\hline AU02 & & & & & & & & -0.24 & 0.25 \\
\hline AU10 & & -0.31 & -0.29 & -0.31 & 0.20 & 0.24 & & & 0.21 \\
\hline AU11 & & -0.23 & & & & & & & 0.36 \\
\hline PE01 & & & -0.22 & & & & & 0.26 & \\
\hline PE02 & & -0.24 & -0.26 & -0.29 & & 0.28 & & & 0.30 \\
\hline PE10 & & -0.29 & -0.30 & -0.35 & 0.21 & 0.30 & & & \\
\hline PE11 & & -0.27 & -0.21 & -0.26 & & & & & 0.36 \\
\hline$A L$ & 0.27 & 0.35 & 0.46 & 0.41 & & -0.24 & & & -0.49 \\
\hline $\mathrm{GH}$ & & & & & & 0.21 & & 0.27 & \\
\hline $\mathrm{AH}$ & 0.24 & 0.27 & & & & & & & \\
\hline HD & & & & -0.21 & & & & -0.28 & 0.42 \\
\hline$m$ & 1.00 & & & & & & & & \\
\hline$M$ & & 1.00 & & & & & & & \\
\hline$t$ & 0.76 & 0.72 & 1.00 & & & & & & \\
\hline etp & & 0.69 & 0.57 & 1.00 & & & & & \\
\hline$Q$ & -0.35 & -0.64 & -0.60 & -0.37 & 1.00 & & & & \\
\hline$h b$ & -0.45 & -0.43 & -0.56 & -0.66 & 0.70 & 1.00 & & & \\
\hline pmo & -0.46 & & -0.29 & & 0.64 & 0.81 & 1.00 & & \\
\hline alt & -0.67 & & -0.52 & & 0.46 & 0.44 & 0.55 & 1.00 & \\
\hline lat & & -0.57 & -0.39 & -0.59 & & & -0.30 & -0.40 & 1.00 \\
\hline
\end{tabular}

cept for $M$ and $Q$. Each curve joins the different classes of the same trait from the lowest class to the highest. The name of each trait is always placed close to the highest class point. Finally, active traits are always presented by solid lines, while additional variables are projected on the same 1-2 plan and may be drawn with dotted lines. To make the presentation clear, different traits are not presented together on the plot; but the same 1-2 plan is always shown in figures 1-7. 
Table V. Relative contribution of each active variable (28 agronomic variables) to the inertia explained by the first 2 axes.

\begin{tabular}{|c|c|c|}
\hline Agronomic variables & Axis 1 & Axis2 \\
\hline RSO1 & 0.6 & 8.1 \\
\hline $\mathrm{RSO} 2$ & 0.3 & 3.5 \\
\hline RS10 & 0.7 & 2.6 \\
\hline RS11 & 2.4 & 4.4 \\
\hline FR01 & 6.5 & 5.6 \\
\hline FR02 & 0.9 & 8.1 \\
\hline FR10 & 4.8 & 1.6 \\
\hline FR11 & 1.7 & 7.0 \\
\hline SP01 & 3.3 & 1.0 \\
\hline SP02 & 0.7 & 0.3 \\
\hline SP10 & 5.3 & 3.3 \\
\hline SP11 & 3.4 & 0.3 \\
\hline SU01 & 2.6 & 1.1 \\
\hline SU02 & 2.4 & 7.8 \\
\hline SU10 & 9.6 & 2.6 \\
\hline SU11 & 2.3 & 3.8 \\
\hline AU01 & 0.7 & 2.8 \\
\hline $\mathrm{AUO2}$ & 4.3 & 8.5 \\
\hline $\mathrm{AU} 10$ & 6.5 & 0.0 \\
\hline$A U 11$ & 6.4 & 1.3 \\
\hline PE01 & 1.5 & 0.6 \\
\hline PE02 & 4.8 & 2.0 \\
\hline PE10 & 5.3 & 0.2 \\
\hline PE11 & 5.1 & 3.5 \\
\hline$A L$ & 8.8 & 1.5 \\
\hline $\mathrm{GH}$ & 0.3 & 8.9 \\
\hline $\mathrm{AH}$ & 5.5 & 0.5 \\
\hline$H D$ & 3.0 & 9.1 \\
\hline
\end{tabular}

\section{Relationships within agronomic traits}

All the highest values of the 4 rust susceptibility variables (fig 1) are on the negative side of axis 2. But it can be seen that the curve of rust susceptibility at Le Pin-au-Haras (RS11) is not in good correspondence with the others. On the other hand, growth habit (GH) seems to be in good relationship with rust susceptibility: prostrate populations are more susceptible, while erect ones are more resistant. Finally, heading date (HD) which is presented on the same plot, seems to be negatively correlated with rust susceptibility: in fact, early and more susceptible populations are on the same negative side of axis 2.

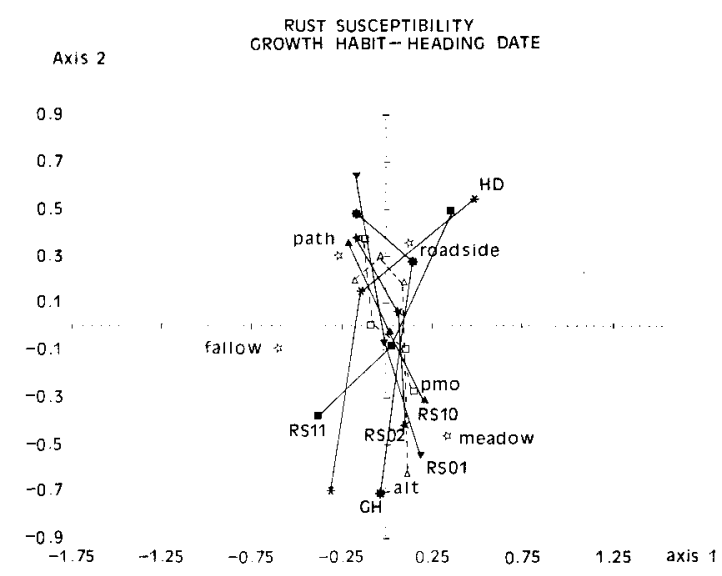

Fig 1. First 1-2 plan of the multivariate correspondence analysis: rust susceptibility, growth habit and heading date.

The 4 frost susceptibility curves (fig 2) appear closer along axis 2; the less frost-susceptible populations are also prostrate populations. Indeed, there is a good relationship between frost susceptibility and growth habit.

Spring growth traits are also shown (fig 3): the curve of Mont de Marsan (SPO2) has a different contour compared to the 3 other locations. But the 4 highest points are grouped in the same square.

Summer aspect and autumn regrowth (fig 4) presented anomalous point positions: for instance, SU02 is not grouped with the others and $\mathrm{AU02}$, which is clearly correlated to $\mathrm{SU} 02$ is also in disagreement. Finally, the AU01 curve is oriented on the opposite side of axis 1 . Howev$\mathrm{er}$, on the whole, axis 1 appears to be one of vigour.

Finally, the 4 persistence curves (fig 5) are grouped along axis 1 . As can be seen compared

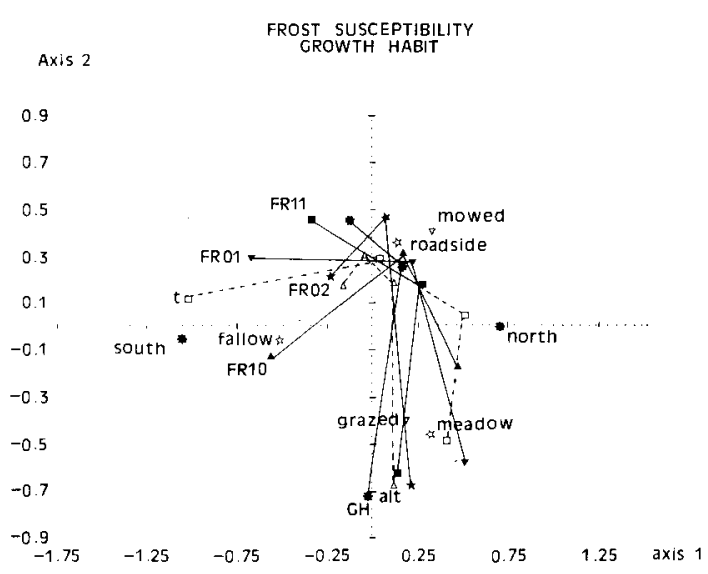

Fig 2. First 1-2 plan of the multivariate correspondence analysis: frost susceptibility and growth habit. 


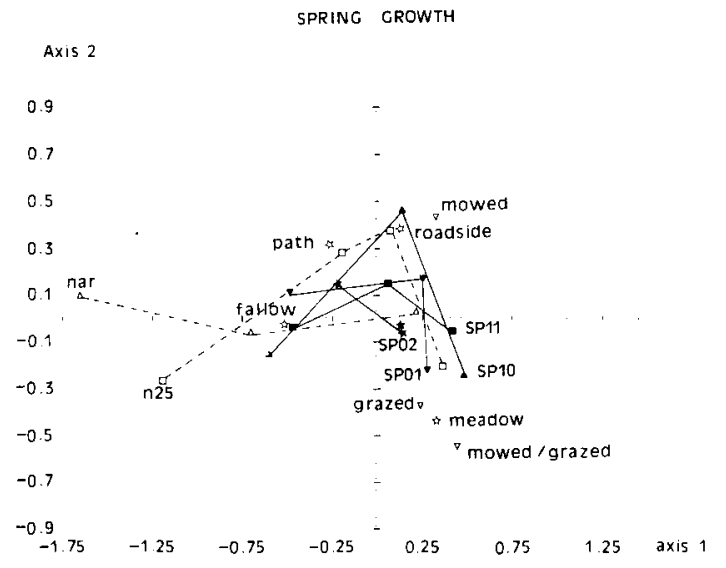

Fig 3. First 1-2 plan of the multivariate correspondence analysis: spring growth.

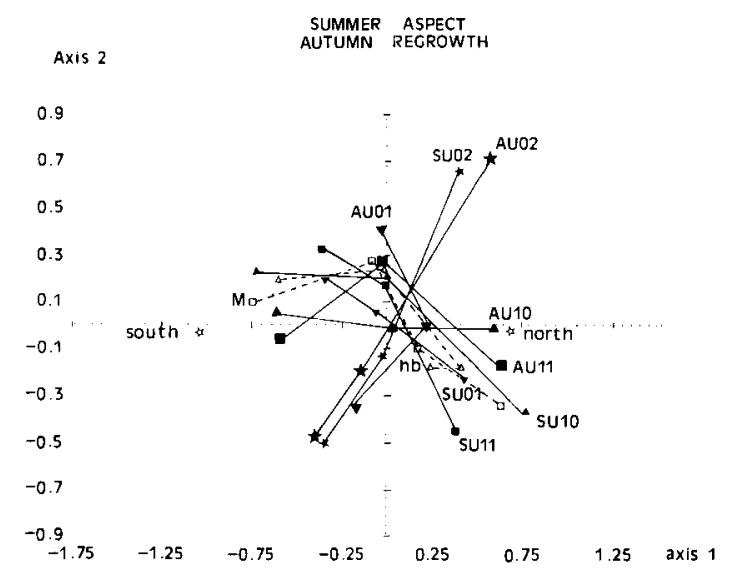

Fig 4. First 1-2 plan of the multivariate correspondence analysis: summer aspect and autumn regrowth.

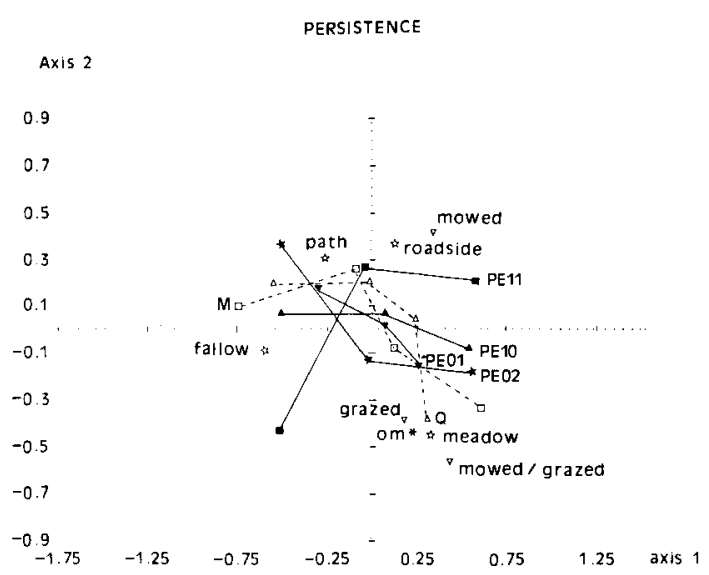

Fig 5. First 1-2 plan of the multivariate correspondence analysis: persistence.

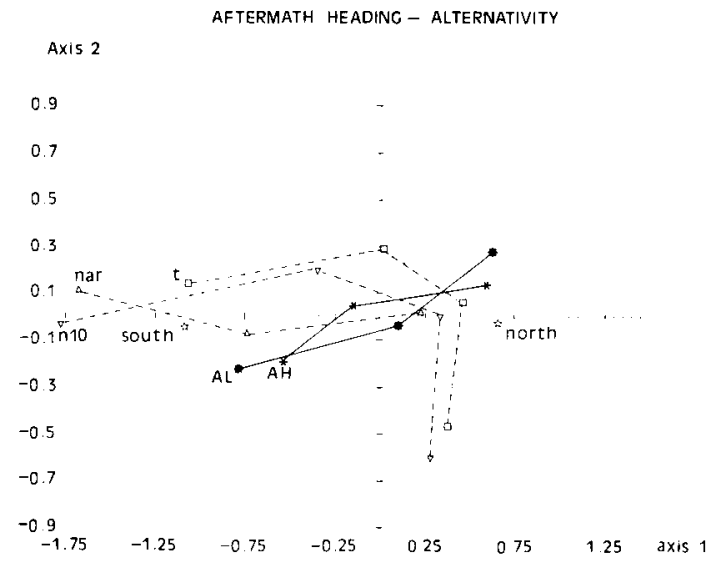

Fig 6. First 1-2 plan of the multivariate correspondence analysis: aftermath heading and alternativity.

to figure 6 there are some relationships between persistence, alternativity and aftermath heading curves. In fact, the more persistent populations (positive side of axis 1) are not alternative and, on the whole, have a low level of aftermath heading. On the other hand, alternative populations generally present a high level of aftermath heading and lower persistency.

\section{Relationships between agronomic and ecogeographical traits}

Rust susceptibility (fig 1) appears to be connected with altitude (alt) and accumulated rainfall from March to October (pmo); populations from a high area, with a high level of rainfall, seem to be more susceptible to rust. This is confirmed by the high coefficients of linear correlation between altitude and RS01 $(r=0.46)$ or RS11 $(r=0.38)$ (cf table IV) Moreover, the relative position of meadow, roadside and path points on axis 2 indicates a relationship between habitat and rust susceptibility: meadow should be a location where populations are more susceptible, while roadside and path appear to be favourable sites for collecting more resistant material. Finally, fallow is apart from the others (see fig 1).

Frost susceptibility and growth habit (fig 2) are compared with mean annual temperature ( $t)$, altitude (alt), latitude (lat) and farming management. We observed a very good correspondence between frost susceptibility and temperature curves, especially for FR01 $(r=0.45)$. The altitude curve also indicates that prostrate populations from the highest areas, are less susceptible 
of frost; the relative position of north and south points on axis 1 indicates that southern ecotypes are more frost-susceptible than northern ecotypes. Finally, it is noted that "roadside" and "mowed" are close to "erect" growth habit, while "meadow" and "grazed" are on the opposite side of axis 2, near "prostrate" growth habit.

The next diagram (fig 3) show us spring growth in relation to different site variables: nar (number of months with aridity), n25 (number of months with mean maximum temperature $>25^{\circ} \mathrm{C}$ ), habitat and farming management. In fact, axis 1 separates warm and arid sites on the left (negative side) from cool and wet climatic sites on the right (positive side). Hence the original sites of the best spring growth populations are distinguished by wet and fresh climatic data. The relative position of "meadow", "mowed" and "grazed" on the positive side of the vigour axis 1 indicates the influence of habitat and farming management on spring growth. By contrast, "path" and "fallow" are located on the negative side of axis 1.

Except at Mont de Marsan (SU02), summer aspect (fig 4) is in good correlation with latitude, but also with climatic factors linked with temperature: for instance, we observe that curves of hydric balance ( $h b=$ pmo-etp), and mean daily maximum temperature of the warmest month $(M)$ are nearly confounded with the 3 other summer curves. These results are confirmed by table IV: for example, SU10 is negatively correlated with $M(r=-0.36)$ and $t(r=-0.46)$.

Persistency (fig 5 ) seems to be more correlated with habitat, farming management and influenced by organic manure applications (om). Indeed, as we can see, the persistency level of wild populations seems to be linked with level of farming utilisation and intensification. But climatic data, such as $M$ or $Q$ (humidity index), are also in relationship with this agronomic trait: wet and cool climates are better for grass persistency.

Finally, we can see (fig 6) that alternativity (ie ability to flower in sowing year) and aftermath heading are influenced by latitude, but also by temperature and aridity (nar, n10). The warmer a climate gets, for instance in a southern region, the more alternative and aftermath heading populations become.

Similar analyses were carried out with the other ecological variables such as humidity situation, specific abundance, level of maturity and trampling intensity, but no consistent relationship between these traits and the agronomic traits could be extracted from the results.
In order to summarize and illustrate these results about relationships between agronomic traits and ecogeographical data, the main administrative regions of France have been projected, always on the same 1-2 plot, as additional variables (fig 7).

Finally, tables VI and VII give the mean of some agronomic traits, for the lower (1) and the upper (4) classes of the most important additional variables. These means are compared to the overall mean calculated on 547 populations and underlined when the mean is above the overall mean. Finally, in these tables, values which do not significantly differ (at the $5 \%$ level) from the overall mean are given in italics.

We can verify (table VI) that rust susceptibility is influenced by altitude and rainfall, while frost susceptibility is mainly linked to temperature. Table VII indicates that some ecological features, like habitat and farming management, also influence some agronomic traits such as spring growth or persistence, while climatic variables seem to be more important for explaining summer aspect, aftermath heading or alternativity.

\section{DISCUSSION AND CONCLUSION}

As reported in the introduction, relationships between agronomic traits of wild ryegrass populations and some ecogeographical factors have been studied by a number of different authors. However, most of them worked on one specific character, for instance winter hardiness, or early

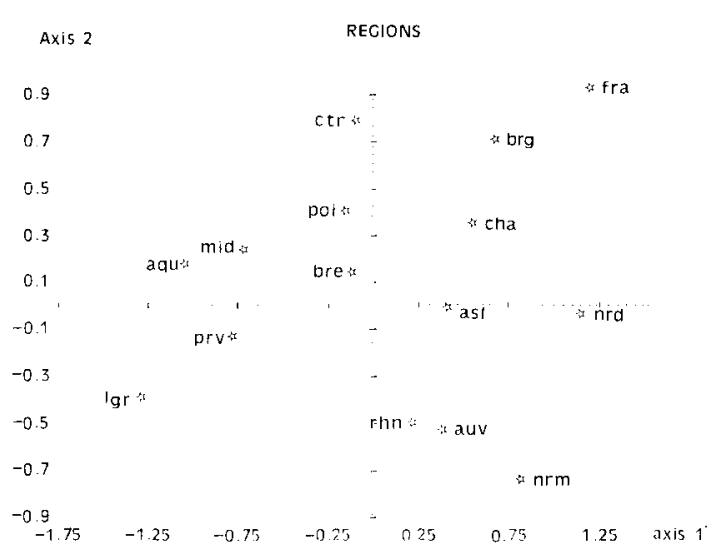

Fig 7. First 1-2 plan of the multivariate correspondence analysis: projection of the 15 regions ( $\mathrm{nrd}=$ Nord-Picardie; $\mathrm{nrm}=$ Normandie; bre = Bretagne-Pays de Loire; $c t r=$ Centre; auv = Auvergne-Limousin; aqu = Aquitaine; mid = Midi-Pyrénées; poi $=$ Poitou-Charentes; cha = Champagne-Ardennes-lle-deFrance; asl = Alsace-Lorraine; brg = Bourgogne; fra = Franche-Comté; rhn = Rhône-Alpes; prv = Provence-AlpesCote d'Azur; lgr = Languedoc-Roussillon). 
Table VI. Means of rust and frost susceptibility, growth habit and heading date for the lower (1) and the upper (4) classes of the most important additional variables.

\begin{tabular}{|c|c|c|c|c|c|c|}
\hline & \multicolumn{4}{|c|}{ Rust susceptibility } & \multicolumn{2}{|c|}{ Growth habit } \\
\hline & RSO1 & RSO2 & $R S 10$ & $R S 11$ & & $G H$ \\
\hline $\begin{array}{l}\text { Roadside } \\
\text { Meadow }\end{array}$ & $\begin{array}{l}4.84 \\
5.32 \\
\end{array}$ & $\frac{2.88}{2.89}$ & $\begin{array}{l}3.84 \\
4.10 \\
\end{array}$ & $\begin{array}{l}3.61 \\
3.66\end{array}$ & $\begin{array}{l}\text { Path } \\
\text { Roadside } \\
\text { Meadow }\end{array}$ & $\begin{array}{l}3.56 \\
3.71 \\
4.55 \\
\end{array}$ \\
\hline $\begin{array}{l}\text { alt (1) } \\
\text { alt (4) }\end{array}$ & $\begin{array}{l}4.90 \\
5.68 \\
\end{array}$ & $\begin{array}{l}2.66 \\
3.02 \\
\end{array}$ & $\begin{array}{l}3.91 \\
4.12 \\
\end{array}$ & $\begin{array}{l}3.51 \\
4.10 \\
\end{array}$ & $\begin{array}{l}\text { pmo (1) } \\
\text { pmo (4) }\end{array}$ & $\begin{array}{l}3.53 \\
4.12 \\
\end{array}$ \\
\hline $\begin{array}{l}m(1) \\
m(4)\end{array}$ & $\frac{5.70}{4.70}$ & $\frac{2.90}{2.54}$ & $\frac{4.18}{3.73}$ & $\begin{array}{l}4.02 \\
3.63\end{array}$ & $\begin{array}{l}\operatorname{etp}(1) \\
\operatorname{etp}(4)\end{array}$ & $\frac{4.18}{3.66}$ \\
\hline $\begin{array}{l}\text { pmo (1) } \\
\text { pmo (4) }\end{array}$ & $\begin{array}{l}4.89 \\
5.23 \\
\end{array}$ & $\begin{array}{l}2.56 \\
2.96 \\
\end{array}$ & $\begin{array}{l}3.86 \\
4.11 \\
\end{array}$ & $\begin{array}{l}3.54 \\
\underline{3.93} \\
\end{array}$ & $\begin{array}{l}Q(1) \\
Q(4)\end{array}$ & $\begin{array}{l}3.58 \\
4.21 \\
\end{array}$ \\
\hline $\begin{array}{l}h b(1) \\
h b(4)\end{array}$ & $\begin{array}{l}4.84 \\
5.35 \\
\end{array}$ & $\begin{array}{l}2.68 \\
2.91 \\
\end{array}$ & $\begin{array}{l}3.73 \\
4.15 \\
\end{array}$ & $\frac{3.83}{3.90}$ & $\begin{array}{l}h b(1) \\
h b(4)\end{array}$ & $\begin{array}{l}3.59 \\
4.18 \\
\end{array}$ \\
\hline \multirow[t]{3}{*}{ Overall mean } & 5.13 & 2.76 & 3.97 & 3.74 & Overall mean & 3.87 \\
\hline & \multicolumn{4}{|c|}{ Frost susceptibility } & \multicolumn{2}{|c|}{ Heading date } \\
\hline & FRO1 & FRO2 & FR10 & $F R 11$ & & $H D$ \\
\hline $\begin{array}{l}\text { Path } \\
\text { Meadow }\end{array}$ & $\frac{5.28}{4.72}$ & $\frac{5.00}{4.34}$ & $\begin{array}{l}2.30 \\
2.31\end{array}$ & $\frac{5.84}{5.80}$ & Roadside & 150.04 \\
\hline $\begin{array}{l}\text { alt (1) } \\
\text { alt (4) }\end{array}$ & $\frac{5.32}{4.79}$ & $\frac{5.06}{4.55}$ & $\frac{2.47}{2.25}$ & $\frac{5.81}{5.74}$ & $\begin{array}{l}\text { Path } \\
\text { Meadow }\end{array}$ & $\frac{149.53}{146.41}$ \\
\hline $\begin{array}{l}\text { lat (1) } \\
\text { lat (4) }\end{array}$ & $\frac{5.71}{4.54}$ & $\frac{4.95}{4.76}$ & $\frac{3.09}{2.08}$ & $\frac{6.00}{5.78}$ & $\begin{array}{l}\text { lat (1) } \\
\text { lat (4) }\end{array}$ & $\begin{array}{l}144.16 \\
151.36 \\
\end{array}$ \\
\hline $\begin{array}{l}t(1) \\
t(4)\end{array}$ & $\begin{array}{l}4.48 \\
\underline{5.80} \\
\end{array}$ & $\begin{array}{l}4.58 \\
5.00 \\
\end{array}$ & $\begin{array}{l}2.06 \\
2.92 \\
\end{array}$ & $\begin{array}{l}5.63 \\
5.90 \\
\end{array}$ & $\begin{array}{l}\text { pmo (1) } \\
\text { pmo (4) }\end{array}$ & $\frac{149.74}{145.90}$ \\
\hline Overall mean & 5.02 & 4.80 & 2.31 & 5.80 & Overall mean & 148.24 \\
\hline
\end{tabular}

spring growth. In fact, the full range of environmental factors of the original sites may influence all the agronomic characteristics.

Rust susceptibility has been reported by Humphreys (1989) to be negatively correlated with heading date $(r=-0.6)$. Our experiment confirms this result, but we can also observe a good relationship between rust susceptibility and growth habit. A possible explanation may be that a prostrate plant, with leaves near the soil and close to other leaves, could be more easily contaminated by fungi than an erect plant. Further, the anomalous position of RS11 can be explained by the fact that some different races of rust (Puccinia coronata) probably occurred at different experimental sites.

Concerning growth habit, we also observed a good correlation between this trait, the original habitat and the type of utilisation: prostrate plants come from 'grazed meadow', while erect ones are from 'roadside', 'path' and 'mowed' locations. This result has been reported by Van Dijk (1989) in Plantago major. For this common pasture species, he writes that the roadside types have become adapted to trampling by being erect, while the lawn type are adapted to short and frequent cutting by being prostrate. Tyler and Chorlton (1976) also indicate that the increase in organic 
Table VII. Means of spring growth, summer aspect, persistence, aftermath heading and alternativity, for the lower (1) and the upper (4) classes of the most important additional variables.

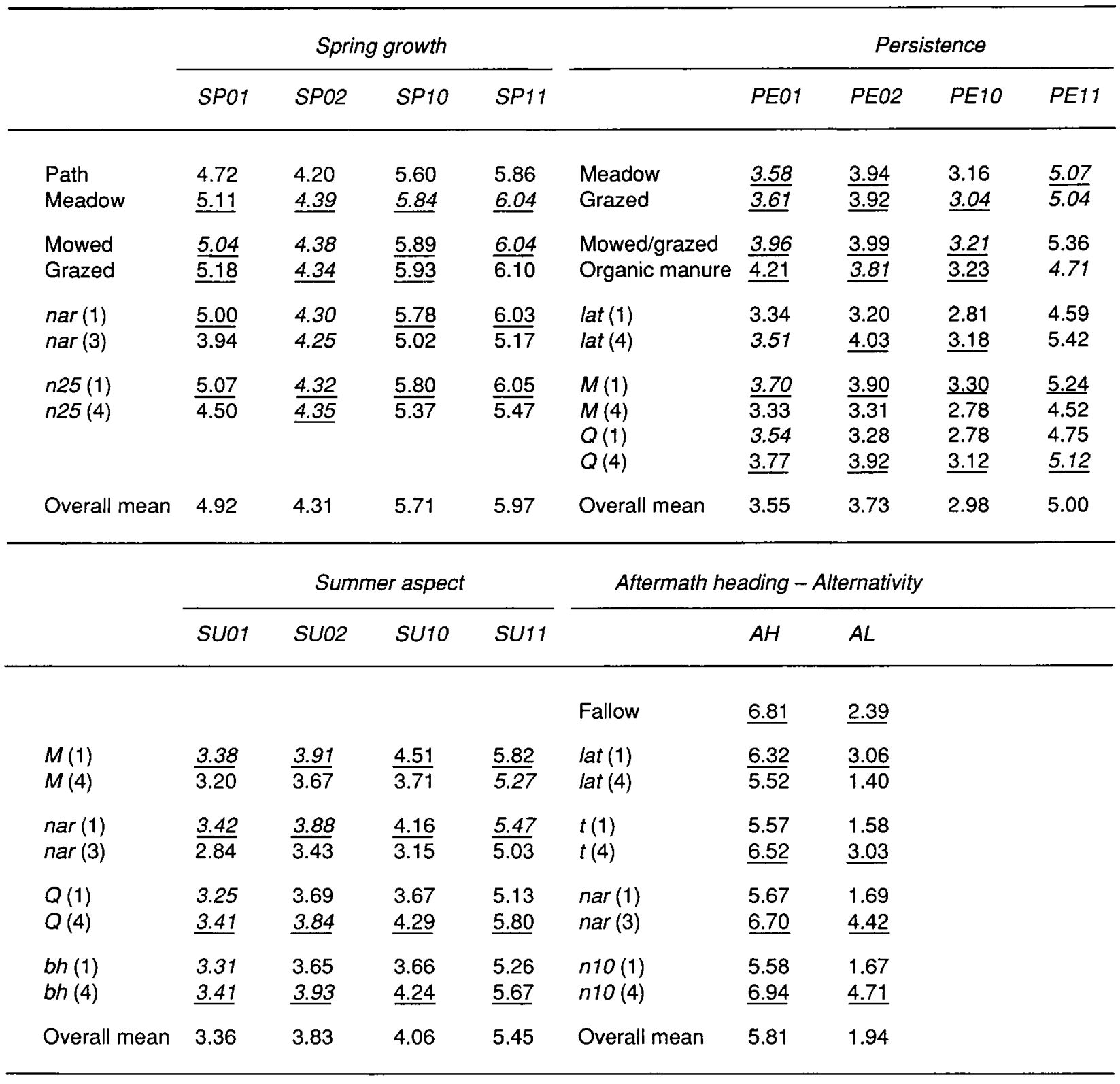

manure appears to favour survival of erect and low tillers. We did not find such a result, probably because of the small number (33) of original sites with organic manure application. Forde and Sukling (1980) reported that plants from sunny aspects were more erect than those from hilltop or shady aspects. On the other hand, according to Lorenzetti et al (1971) we know that erect plants from hay types are more frost-susceptible. We have also observed such a result. In fact, frost susceptibility and growth habit seem to be linked.

Concerning frost susceptibility, some other relationships were obtained with altitude, latitude, habitat and especially with temperature. These results have also been observed by Lorenzetti et al (1971), who noted that frost susceptibility is linked in particular with average lowest temperature of the coldest month and that southern ecotypes are the most susceptible. Humphreys and Eagles (1988) working in the glasshouse on freezing tolerance with measures of $L T_{50}$ (temperature at which $50 \%$ mortality occurs), have confirmed this result. But they obtained a negative correlation $(r=-0.46)$ between heading date and $L T_{50}$. Tyler and Chorlton (1978), working on ecotypes from eastern France and Switzerland, also observed a generally lower winter hardiness of early flowering populations except for the Zurich area. On the contrary, in our experiment early populations seemed to be less frost- 
susceptible. But in fact, frost susceptibility has been noticed in the field by leaf damage following winter. This different result could be explained, as Humphreys (1989) says, by the fact that leaf damage (ie visual estimation of winter burn) is not a well-correlated indicator of true winter hardiness.

Regarding heading date, there are some obvious relationships with altitude and rainfall. Similar results have been shown by Veronesi and Falcinelli (1988) who in Festuca arundinacea calculated a positive correlation $(r=0.44)$ between heading date and altitude, as well as between heading date and rainfall $(r=0.39)$. Although we noted the aspect of each population site, we did not observe any consistent correlation with this factor, but Forde and Suckling (1980) have indicated that plants from hilltops headed later than those from sunny and shady aspects.

Spring growth is influenced by habitat and farm management. As observed by Tyler and Chorlton (1978), we can see that populations collected from the more intensively grazed areas (meadows) performed better than those which were underutilised (fallows). As reported by Charmet et al (1989), working on Irish ryegrass populations, spring growth is also affected by temperature.

Summer aspect, which was evaluated by the importance of summer growth and color of leaves, appears very bad for southern populations and the best for northern ones. This agronomic trait is well correlated with latitude and in this way with all temperature and humidity factors. Veronesi and Facinelli (1988) report the same result in tall fescue where summer growth and average lowest temperature of the coldest month are negatively correlated $(r=-0.30)$ while the coefficient of correlation with latitude is 0.36 . The anomalous position of SUO2 and AU02 could be explained by the specific behaviour of Mont de Marsan experimental location. Indeed, as reported by Charmet et al (1990), this location appears to be very different compared to the others for vigour traits since they report some form of specific and regional adaptations in local populations.

Regarding persistency, in Romania Tyler et al (1984) found that populations derived from grazed or trampled sites of relatively high fertility were more persistent than those from underutilised and low fertility sites. For our French populations, the same relationships concerning habitat and farm management can be seen. The presence of organic manure increases persisten- cy. But no good correlation between persistency and trampling intensity has been found. Perhaps the small number of sites where high trampling level was observed can explain why our sample was shifted for the study of this characteristic.

The absence of soil samples and soil analysis does not permit conclusions to be drawn about the relationships which could exist between soil fertility level and vigour of populations collected on the same soils. In New Zealand however, populations from low phosphorus sites were significantly more vigourous than those from high phosphorus sites (Forde and Sukling, 1980).

Correlations between aftermath heading, latitude, temperature and aridity factors may be explained by a phenomenon of resource allocation and adaptive strategy. In fact, populations coming from warm and dry regions have a tendency to create more reproductive than vegetative tillers in order to survive. On the other hand, populations from wet and cool areas are more vigourous and have less aftermath heading because they build more vegetative organs.

Finally, results concerning alternativity (ie low vernalization requirement), which is also linked with latitude, confirm the hypothesis that Lolium perenne species have a distribution area which is restricted by climatic environment. Thus, multivariate correspondence analysis appears to be a useful method to describe large tendencies which link agronomic characteristics of wild ryegrass populations and ecogeographical factors from their original site.

Indeed, the results taken as a whole show us that genetic diversity observed on these indigenous populations is not randomly distributed, but organized according to the diversity of the original environment. This allows us to direct our future collections. In fact, with regard to the agronomic characteristics required, we already know the kind of ecogeographical environment capable of sheltering adequate natural populations. The knowledge of the influence of original environment as a natural selective element should allow us to increase the efficiency of breeding programs by introduction of new resources well adapted to our objectives.

This advance in the study of the relationships between agronomic and ecogeographical factors also tells us something about evolution strategies which can be developed by populations to best adapt to their natural environment.

The advantage of using ecogeographical data in constituting gene banks can be seen in this 
paper. However, as suggested by Peeters et al (1990), it would be interesting to gather populations with identical agronomic characteristics and from the same ecological area, and mate them in order to constitute new genetic resources for plant breeding programs. In the same way, as suggested by Lumaret (1984), the search for isoenzymatic systems as a means of revealing specific adaptation must be investigated. These different points will be presented in further papers.

\section{ACKNOWLEDGMENTS}

The authors wish to thank MD Hayward and JM Prosperi for helpful comments and criticisms.

\section{REFERENCES}

Benzecri JP (1973) L'analyse des Données II. L'Analyse des Correspondances. Dunod, Paris

Benzecri JP (1979) Sur le calcul des taux d'inertie dans l'analyse d'un questionnaire. Cah Anal Données 4 (3), 377-378

Caradus JR, MacKay AC, Woodfield DR, Van den Bosch J, Wewala S (1989) Classification of a world collection of white clover cultivars. Euphytica 42, 183-196

Charmet G, Bion A, Balfourier F (1989) Agronomic evaluation of perennial ryegrass wild populations from Ireland for use in French plant breeding programmes. Agronomie 9, 985-991

Charmet G, Balfourier F, Bion A (1990) Agronomic evaluation of a collection of French perennial ryegrass populations: multivariate classification using genotype $x$ environment interactions. Agronomie 10, 807-823

Erskine W, Adham Y, Holly $L$ (1989) Geographic distribution of variation in quantitative traits in a world lentil collection. Euphytica 43, 97-103

Forde MB, Suckling FET (1980) Genetic resources in high-rainfall hill pastures of New Zealand. II. Description of the ryegrass collection. $N Z J$ Agric Res 23, 179-189

Garnier M (1966) Monographies de la Météorologie Nationale. Valeurs Normales des Hauteurs de Précipitations en France. National Meteorological Office, Paris

Hayward MD, Breese EL (1966) The genetic organization of natural populations of Lolium perenne. 1. Seed and seedling characters. Heredity 21, 287 304
Hayward MD, Breese EL (1968) The genetic organization of natural populations of Lolium perenne. III. Productivity. Heredity 23, 357-368

Humphreys MO (1989) Assessment of perennial ryegrass (Lolium perenne $L$ ) for breeding. II. Components of winter hardiness. Euphytica 41, 99-106

Humphreys MD, Eagles CF (1988) Assessment of perennial ryegrass (Lolium perenne $L$ ) for breeding. I. Freezing tolerance. Euphytica 38, 75-84

Kessier J, Chambraud A (1986) La Météo de la France. JC Lattes

Lorenzetti F, Tyler BF, Cooper JP, Breese EL (1971) Cold tolerance and winter hardiness in Lolium perenne. 1. Development of screening techniques for cold tolerance and survey of geographical variation. J Agric Sci (Camb) 76, 199-209

Lumaret $R$ (1984) The role of polyploidy in the adaptive significance of polymorphism at the got 1 locus in the Dactylis glomerata complex. Heredity 52, 153-169

Peeters JP, Wilkes HG, Galwey NW (1990) The use of ecogeographical data in the exploitation of variation from gene banks. Theor Appl Genet 80, 110112

Prosperi JM, Gensollen V, Olivieri I, Mansat P (1989) Observations sur la répartition et l'écologie de luzernes annuelles et de trèfle souterrain en Corse. In: Proceedings 17th Int Grassland Congr, Nice (Fra), 4-11 October, 1989, 295-296

Tyler BF (1979) Broadening the genetic basis of crops. Eucarpia Conference, Wageningen, 7 March 1978. In: Proceedings, 105-111

Tyler BF, Chorlton KH (1976) Ecotypic differentiation in Lolium perenne populations. Rep Welsh Plant Breed Stn 1975, Aberystwyth, UK, 14-15

Tyler BF, Chorlton KH (1978) Characterisation of perennial ryegrass ecotypes from eastern France and Switzerland. Rep Welsh Plant Breed Stn 1978, Aberystwyth UK, 43-46

Tyler BF, Chorlton KH, Thomas ID (1984) Characterisation of collected Lolium perenne populations. Rep Welsh Plant Breed Stn 1983, Aberystwyth, UK, 29-32

Van Dijk H (1989) Genetic variability in Plantago species in relation to their ecology. 4. Ecotypic differentiation in $P$ major. Theor Appl Genet 77, 749-759

Veronesi F, Falcinelli M (1988) Evaluation of an Italian germplasm collection of Festuca arundinacea Schreb through a multivariate analysis. Euphytica $38,211-220$

Volle M (1985) Analyse des.Données. Economica, Paris

Weltzien E (1989) Differentiation among barley landrace populations from the Near East. Euphytica 43, 29-39 